ing to Strabo, p. 179 , it was only 63 Roman miles from Tarascon to the beginning of the ascent of the Alps on the Durance route.

My fifth assumption is that in Polybius, 3.42 $8 \mathrm{I}$, 'the "four days' march from the sea" is to be reckoned from the nearest point of the coast, and not from the point where Hannibal himself turned inland.' I neither said nor assumed that it was to be reckoned from the nearest point of the coast. I followed Professor Spenser Wilkinson in supposing that Polybius reckoned the distance by the marches of Scipio's army. I have motored from Nîmes to Aiguesmortes, Les Saintes-Maries, and St.-Gilles, and I have gone by train to Narbonne. Hence I do not believe that Hannibal followed the coast to Aiguesmortes, as $\mathrm{Mr}$. Cecil Torr supposes. I agree with Mr. Bonus (p. 26) that he would turn inland at Agde to avoid the lagoons and salt-marshes. Now Agde, as Mr. Bonus says, is about 80 miles from Tarascon. Since Tarascon is only about 35 miles from the sea, I cannot believe that Polybius would have said in effect that it was 80 . And anyhow it does not affect the main argument, for $\mathrm{Mr}$. Bonus thinks, as I do, that Hannibal crossed at Tarascon.

Finally, Mr. Bonus complains that $I$ do not specify any of the points in which he is contradicted by Livy and Polybius. Surely he understands that, when the foundation of his theory is demolished, it would be a waste of time to criticize the details. I have already said that he begins by declaring Polybius, $3 \cdot 39$, to be spurious. Till he can induce any competent scholar to accept that opinion, it is unnecessary to discuss the fabric which he builds on it;

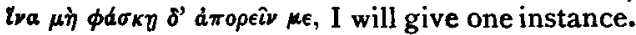
On p. I 8 he says 'the 800 stades represent the distance from Tarascon to the Rhone-Isère confluence [Mr. Bonus thinks the Island lay to the north of the Isère]. It is the same piece of road to which Livy alludes (2I. 3I) when he says that after four days' march from the Durance, Hannibal reached the "Island." Livy's words are quartis castris ad Insulam peruenit (2I. 3I $\$ 4$ ). He says not a word about the Durance, and the context shows

distances are merely inferences from the number of days, it is unnecessary to be more exact. But why, after reckoning 600 stades as about 66 English miles, I made 800 stades nearly 92, I cannot say. I should have said 88 . clearly that the four days' march is measured from the Rhone crossing. The Durance is not mentioned till $\S 9$. Polybius says in $3.49 \S 5$

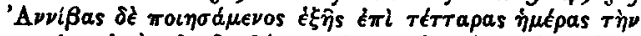

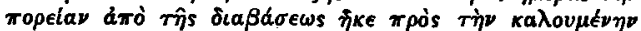

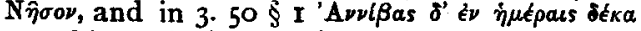

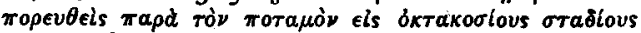

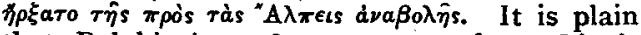
that Polybius' $49 \S 5$ corresponds to Livy's 3I $\$ 4$ and Polybius' four days' march from the crossing to Livy's quartis castris. And it is equally plain that the march of 800 stades in ten days to the ascent of the Alps is not the march of four days to the Island. Therefore Mr. Bonus' statements are clearly at variance with both Livy and Polybius.

Yours truly,

R. L. DUNBabin.

\section{University of Tasmania.}

\section{To the Editors of the CLASSICAL REviEw.}

DEAR SIRS,

May I ask that you give space in the Classical Review to this request?

I am preparing for publication a complete collation of the MSS. of Petronius. A MS., once at Messina but now lost, is known only through a collation made by Otto Jahn in 1839 (Bücheler, ed. mai., p. xx). Bücheler used this collation, and Beck secured a copy of it for his work on the Petronius MSS.

Three copies of the Bipontine edition of 1790 , with notes and collations by Jahn, are listed in. the sale catalogue of his library, issued by Joseph Baer, Max Cohn and Sons and M. Lempertz in 1870 (Nos. 6490, 6491, 6492 in Part I). Some of his books went to the late Professor J. E. B. Mayor, part of whose library was purchased by Messrs. Bowes and Bowes of Cambridge, then dispersed.

It would greatly further my work if the copy of Jahn's Bipontine edition with his collation of the Messina MS. could be found. Anyone who has in his possession any one of the copies mentioned will confer a great favor upon me by communicating with me.

$$
\begin{aligned}
& \text { Yours truly, } \\
& \text { EvaN T. SAGE, } \\
& \text { Professor of Latin. }
\end{aligned}
$$

University of Pittsburgh.

\title{
SUMMARIES OF PERIODICALS
}

\section{THE CLASSICAL WEEKLY.}

Vol. XXVI. NoS. I-7 (OCTOBER-NOVEMBER, 1932).

J. Stinchcomb, Literary Interests of a Roman Magnate (Q. Tullius Cicero). Documented sketch of his life, character, and literary activities. L. R. Shero, Xenophon's Portrait of a Young Wife. Discusses how far X., who is the rather priggish husband Ischo machus, is presenting the normal views or his generation, and how far notions of his own. A. D. Fraser, The Suitors' Competition in Archery (Odyssey XXI. 419-23). Iron axeheads (of the Syrian spectacles type), with holes all ready for the test, are known

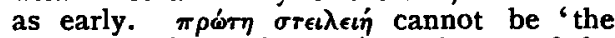
foremost point of the haft' or 'the top of the handle.' Translate 'the arrow did not miss the entrance of the hole (or the actual hole) in every one of the axes, but went right 